\title{
Pengendali PID pada Motor DC dan Tuning Menggunakan Metode Differential Evolution
}

\section{PID Controllers on DC Motors and Tuning Using the Differential Evolution Method}

\author{
Siti Fatimah Anggraini ${ }^{*}$, Alfian Ma'arif ${ }^{2 *}$, Riky Dwi Puriyanto ${ }^{3}$ \\ 1,2,3 Department of Electrical Engineering, Universitas Ahmad Dahlan \\ siti1600022051@webmail.uad.ac.id ${ }^{1}$, alfianmaarif@ee.uad.ac.id ${ }^{2}$, rikydp@ee.uad.ac.id ${ }^{3}$
}

\begin{abstract}
Abstrak - Penggunaan PID controller pada sistem industri sangat umum digunakan dalam menentukan kepresisian suatu feedback yang diberikan dengan keluaran sesuai dengan keinginan pengguna. Namun pada umumnya optimalisasi masih menggunakan cara manual yaitu trial dan error pada tuning gain terhadap nilai $\mathrm{Kp}$, Ki, dan Kd. Kendala tersebut dapat diatasi dengan melakukan pendekatan fungsi dan mengaplikasikan nilai tuning dengan metode Diferensial Evolusi. Penggunaaan tuning PID pada implementasinya menggunakan motor DC untuk menentukan kecepatan putar motor dengan keluaran yang stabil. Hasil yang didapatkan berupa sinyal keluaran atau respon sistem terhadap putaran motor DC dengan menampilkan nilai risetime, settlingtime, dan overshoot. Pengoptimalan nilai dilakukan dengan pencarian nilai terbaik pada setiap iterasi dan diaplikasikan sebagai tuning $\mathrm{Kp}$, Ki, dan Kd tanpa harus melakukan cara manual. Hasil pengujian parameter Diferensial Evolusi menunjukkan efesiensi pengoptimalan tuning dan memberikan hasil keluaran yang baik dengan implementasinya terhadap plan hardware motor $D C$.
\end{abstract}

Kata Kunci: PID controller, Motor DC, Pemyetelan, Diferensial Evolusi.

\begin{abstract}
The use of PID in industrial systems is very commonly used in determining the optimal accuracy of the output. However, several studies still uses manual methods for the optimization, namely trial and error on tuning gain with values of Kp, Ki, and Kd. This problem could be overcome applying the tuning value with the Evolution Differential method. The use of PID tuning in its implementation in this study uses a DC motor to determine the rotational speed of the motor with a stable output. Based on the results, we can see the value of rise time, settling time, and overshoot based on an output signals. The optimization was done by finding the best value in iteration and applying it as $K p$, Ki, and Kd tuning without having to do the manual method. The results of testing the Differential Evolution parameters show the efficiency of tuning optimization and provide good output with the implementation of the DC motor hardware plan.
\end{abstract}

Keywords: PID(Proportional-Integral-Derivative controller), Motor DC, Tuning, Differential Evolution.

\section{Pendahuluan}

Proportional-Integral-Derivative (PID) controller merupakan mekanisme umpan balik yang biasa digunakan pada sistem kendali industri. Fungsi PID adalah untuk mengetahui ketepatan presisi suatu instrumentasi pada umpan balik atau biasa disebut sebagai feedback. PID

TELKA, Vol.6, No.2, November 2020, pp. 147 159

ISSN (e): 2540-9123

ISSN (p): 2502-1982 
tuning dilakukan untuk menentukan nilai gain pada sebuah mikrokontroler yang akan diimplementasikan untuk mendapatkan respons sistem yang diinginkan. Masalah yang dialami pada proses penyelesaiannya terletak pada penentuan nilai yang akan digunakan sebagai gain untuk mendapatkan respons sistem dari tuning yang dilakukan.

Penyetelan/tuning biasanya dilakukan menggunakan metode trial dan error untuk menentukan nilai tuning yang akan di masukkan ke dalam gain $K p, K i$ dan $K d$. Pada permasalahan tuning manual PID, solusi Diferensial Evolusi (DE) dapat digunakan untuk pencarian nilai gain [1]. DE digunakan untuk mendapatkan penyelesaian dengan evolusi baru sebagai salah satu langkah pada suatu masalah. Pada algoritma DE, vektor sidang baru diciptakan secara acak dengan menggabungkan tiga strategi percobaan $\mathrm{DE}$ dan tiga pengaturan parameter di setiap generasi [2]. DE merupakan sebuah model stokastik yang mesimulasikan evolusi biologis [3]. DE dilengkapi dengan tiga komponen algoritmik yang diaktifkan dengan cara probabilistik dengan perbedaan berbasis strategi gangguan pada langkah mutasi [4]. Pada tahap seleksi acak masalah ini adalah bahwa F dan CR harus dipilih secara acak dari distribusi seragam setiap vektor sidang yang dihasilkan dengan menggunakan skema sendiri yang dipilih secara acak juga [5]. Mutasi, Rekombinasi, dan seleksi Diferensial Evolusi menunjukkan bahwa algoritma memberikan kinerja yang cukup baik dan cukup mudah diterapkan dalam kinerja PID. Metode desain PID controller menghasilkan kelemahan dan kekurangan PID sendiri [6]. Untuk mengatasi kelemahan kinerja dalam mengurangi overshoot, dapat dilakukan tuning untuk penyetelan Kp, Ki dan Kd dengan metode Diferensial Evolusi [7]. Selain itu, efektivitas keakuratan sistem kontrol motor dc dapat ditingkatkan dengan cara menyesuaikan parameternya secara optimal [8]. Berdasarkan pemaparan sebelumnya, pada makalah ini dipaparkan sebuah desain pengendali PID pada motor DC dan tuning menggunakan metode DE. Penambahan tuning dengan metode DE dimaksudkan untuk meningkatkan kinerja sistem pengendali yang dibuat.

\section{Metode Penelitian}

Pada penelitian ini dilakukan penentuan parameter PID menggunakan DE dalam upaya untuk menghasilkan nilai $K p, K i$ dan $K d$ yang optimal serta mendapatkan nilai pengujian pada motor DC. Pada bab metode penelitian ini akan dipaparkan tahapan-tahapan yang dilakukan pada penelitian ini, meliputi desain sistem, desain sistem sambungan, perancangan perangkat keras, pengujian sistem, dan algoritma DE yang digunakan pada penelitian ini.

\subsection{Desain Sistem}

Pada penelitian ini, desain sistem ditunjukkan seperti pada Gambar 1. Pada desain sistem ini, keluaran metode Evolusi Diferensial diproses dan selanjutnya diimplementasikan pada perangkat keras.

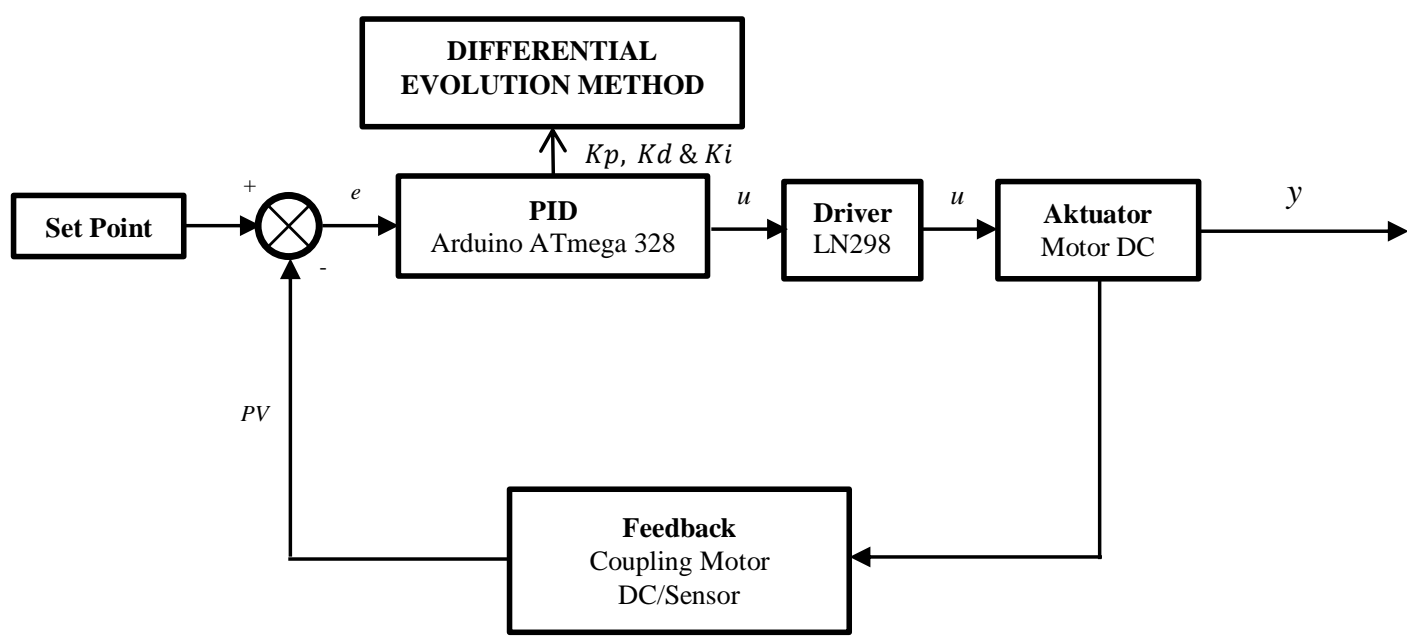

Gambar 1. Plan pengujian atau desain sistem. 
Sistem akan memprogram masukan pada PID mikrokontroler dan akan memberikan nilai terbaik pada gain $K p, K i$ dan $K d$ melalui hasil tuning degan metode Diferensial Evolusi sebelumnya. Pada Gambar 1, setting point (SP) digunakan sebagai acuan utama untuk menjalankan putaran motor/nilai referensi, $e$ adalah nilai error, PID mikrokontroler digunakan untuk mengatur gain $K p, K i$ dan $K d$, $u$ adalah sinyal kendali digital dan analog, driver mengatur presisi motor DC, akuator motor DC saat berputar, feedback nilai yang dihasilkan dari driver dan akuator, present value $(P V)$ adalah nilai feedback, dan y output keluaran atau hasil.

\subsection{Desain Sistem Sambungan}

Pada Gambar 2, ditunjukkan sambungan diagram sistem pengujian pada plan. Pada desain sistem sambungan terdapat driver motor L298N yang berfungsi sebagai feedback dan menentukan presisi pada motor dc, Arduino sebagai PID mikrokontroler digunakan untuk melakukan tuning agar memberikan gain $\mathrm{Kp}$, Ki dan $\mathrm{Kd}$ pada motor dc, dan motor dc akan menghitung nilai putaran dari gain PID mokrokontroler terhadap suatu respons sistem yang akan dihasilkan.

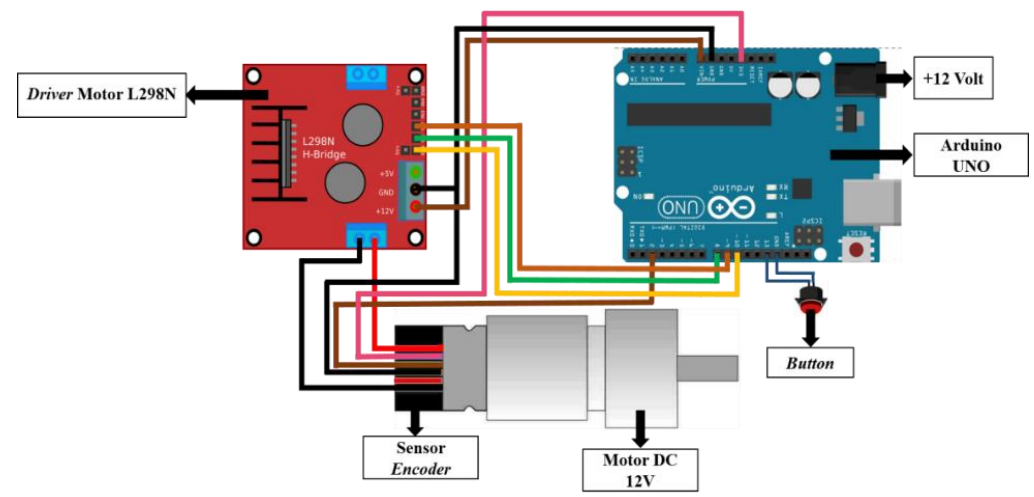

Gambar 2. Desain sistem sambungan.

Masukan dan keluaran dari desain sistem sambungan PID adalah motor dc. Pada sistem yang dibangun ini serial encoder akan menghasilkan posisi sudut pada putaran motor dc, control pin driver akan mengkoneksikan dengan PID mikrokontroler, pwm akan mengolah putaran atau modulasi dari lebar pulsa yang dihasilkan, dan button adalah tombol untuk memulai putaran motor.

Tabel 1. Pin I/O Plan motor DC.

\begin{tabular}{clcccc}
\hline No. & Arduino & L298N & Motor DC & Encoder & Tombol \\
\hline 1 & Pin 13 & - & - & - & Kaki 1 \\
2 & Pin 8 & IN1 & - & - & - \\
3 & Pin 9 & IN2 & - & - & - \\
4 & Pin 10 & ENA & - & - & - \\
5 & Pin 2 & - & - & Out & - \\
6 & 5 Volt & Vcc & - & - & - \\
7 & 3,3 Volt & - & - & 3,3 Volt & Kaki 2 \\
8 & GND & GND & - & GND & - \\
9 & - & M1 & M1 & - & - \\
10 & - & M2 & M2 & - & - \\
\hline
\end{tabular}

\subsection{Perancangan Perangkat Keras}

Perancangan perangkat keras dilakukan dengan membuat gambaran desain tiga dimesi untuk memberikan gambaran keluaran sebuah plan yang akan diuji. Gambar 3 adalah sebuah plan desain tiga dimensi yang akan mengimplementasikan hasil dari metode Diferensial Evolusi. 


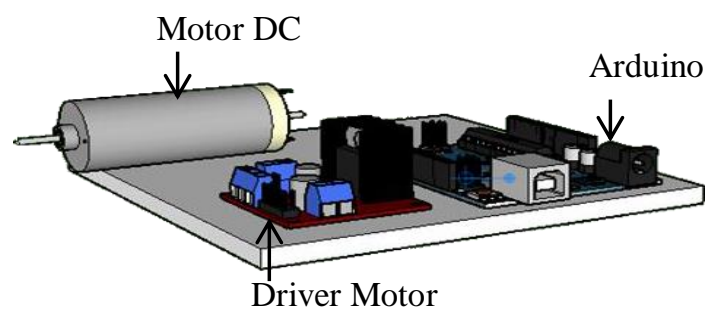

Gambar 3. Desain sistem rangkaian 3D.

\subsection{Pengujian Sistem Metode DE}

Pengujian metode DE yang digunakan pada penelitiana ini diuji dengan simulasi menggunakan Matlab. Simulasi dilakukan dengan mencari nilai terbaik gain tuning $K p, K i$ dan $K d$ yang kemudian ditampilkan pada plan simulink Matlab.

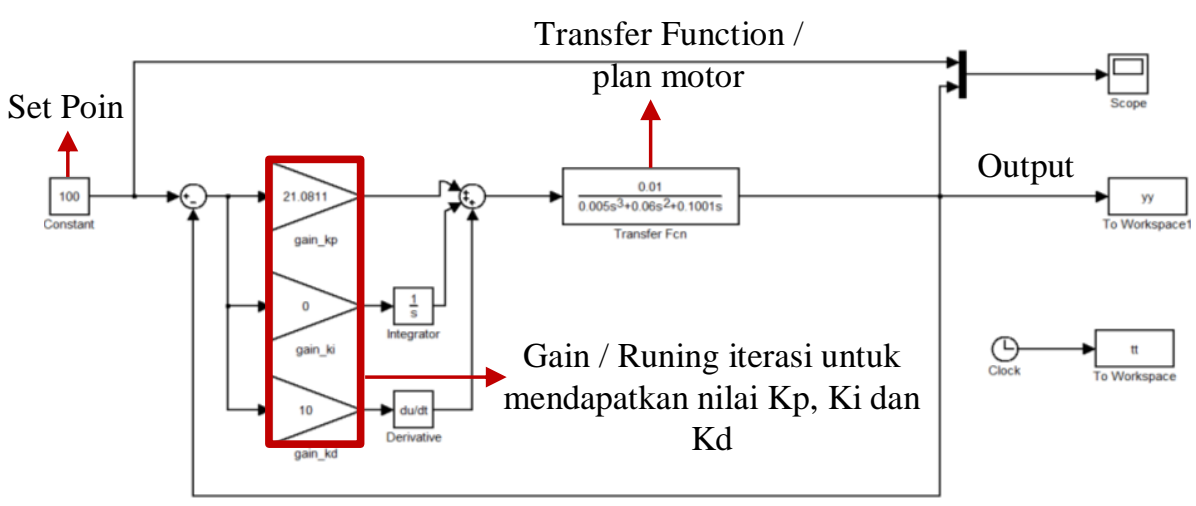

Gambar 4. Simulink program DE.

Berdasarkan hasil simulasi diperoleh respon sistem yang ditunjukkan pada Gambar 5. Pada Gambar 5 dapat diobservasi apakah nilainya melebihi nilai set point yang sudah ditentukan sebelumnya dan dapat diketahui apakah terjadi overshoot atau tidak. Hasil simulasi yang tidak terjadi overshoot dapat digunakan pada tuning PID Motor DC.

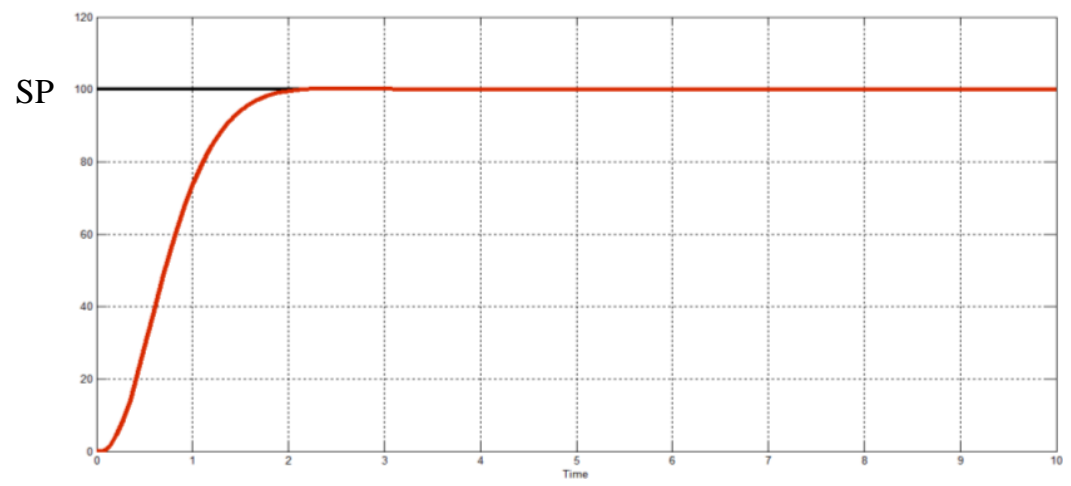

Gambar 5. Respon sistem.

\subsection{Pengujian Sistem dengan Plan Hardware}

Pengujian dengan metode DE diawali dengan membuat tuning parameter secara otomatis, di mana nilai parameter dalam DE sangat berpengaruh terhadap performa DE sendiri. Pada pengujian ini dilakukan sebanyak 100 kali, dan mengambil nilai keluaran dari PID motor dc yang berupa kecepatan. Program float $K p, K i$ dan $K d$ dimasukkan pada pencarian sebelumnya dengan metode Diferensial Evolusi dan dilakukan mode tools untuk menampilkan putaran motor dc yang 
dihasilkan. Pada Gambar 6 menunjukkan data putaran motor DC dengan 100 kali pengambilan data. Selanjutnya, data tersebut dianalisis untuk melihat keadaan sinyal yang dihasilkan.

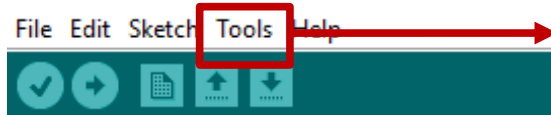

Menampilkan Serial Monitor Data

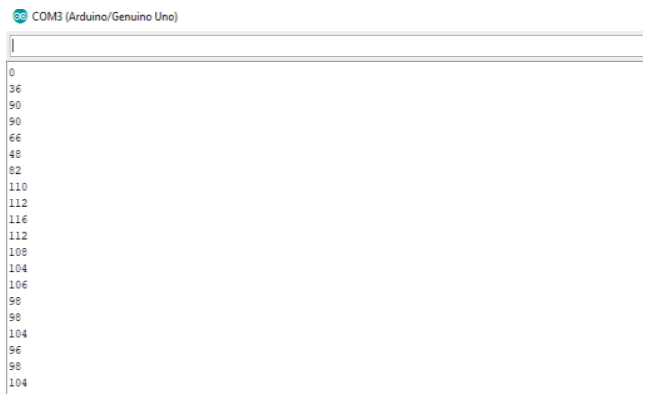

Gambar 6. Menampilkan putaran motor DC.

\subsection{Algoritma Evolusi Diferensial}

Differential Evolution diperkenalkan oleh Storn dan Price pada 1995. Menurut Storn dan Price, DE memiliki 3 buah parameter kontrol yaitu sebagai berikut.

(1) Ukuran populasi.

(2) F yaitu faktor skala berfungsi untuk mengatur difference vektor juga untuk menghindari stagnasi selama proses pencarian.

(3) CR yaitu Crossover dalam nilai $(0,1)$ yang berfungsi sebagai pengendali laju dari perhitungan.

Keuntungan utama metode DE dapat dirangkum dalam tiga poin: tidak memerlukan parameter yang banyak, tidak mudah terjebak dalam solusi lokal, dan cepat untuk berkumpul [10]. Algoritma DE Standar membutuhkan setidaknya 4 langkah sebagai berikut.

1. Inisialisasi generasi populasi yang ditunjukkan pada Persamaan 1.

$$
P_{i j}=\operatorname{rand}_{p 1 j}(0,1)\left(x_{i j}^{u}+x_{i j}^{L}\right)+x_{i j}^{L}
$$

di mana $i$ adalah jumlah individu (populasi), $j$ adalah jumlah variabel, $\operatorname{rand}_{p 1 j}(0,1)$ adalah nilai acak dari 0 hingga $1, x_{i j}^{u}$ adalah batas atas, $x_{i j}^{L}$ adalah batas bawah.

2. Tahap mutasi dengan memilih tiga individu acak dalam populasi,

$$
\left.h_{i j}(t+1)=x_{p 1 j}(t)+F\right)\left(x_{p 2 j}(t)+x_{p 3 j}(t)\right) \text {, }
$$

sedangkan fungsi tanpa solusi lokal adalah,

$$
\left.h_{i j}(t+1)=x_{b j}(t)+F\right)\left(x_{p 2 j}(t)+x_{p 3 j}(t)\right) \text {, }
$$

di mana, $x_{b j}$ adalah individu-individu terbaik. $F$ adalah faktor mutasi yang dipilih antara 0 - 2. Secara umum, dapat diatur dari 0,3 ke 0,6 agar proses konvergensi lebih cepat dan meminimalisir agar prosesnya tidak terjebak dalam solusi lokal;

3. Tahap crossover untuk membuat vektor baru, 


$$
v_{i}(t+1)=\left\{\begin{array}{cc}
h_{i j}(t+1), & \operatorname{rand}_{i j} \leq C R \\
P_{i j}(t), & \operatorname{rand}_{i j}>C R
\end{array}\right.
$$

Dengan $C R$ adalah faktor crossover dalam kisaran [0,1]. Secara umum, dapat diatur dari 0,6 hingga 0,9 .

4. Mengevaluasi vektor dengan membandingkannya dengan orang tuanya. Jika lebih baik daripada orangtuanya, maka lakukanlah penggantian.

$P_{i}(t+1)= \begin{cases}v_{i}(t+1), & f\left(v_{i j}(t+1)\right), \ldots, v_{i n}(t+1)<f\left(x_{x 1}(t), \ldots, x_{i n}(t)\right) \\ x_{i j}, & f\left(v_{i j}(t+1)\right), \ldots, v_{i n}(t+1) \geq f\left(x_{x 1}(t), \ldots, x_{i n}(t)\right)\end{cases}$

Pada Gambar 4 ditunjukkan flowchart iterasi yang menggunakan metode DE dengan ketiga parameternya yaitu $G$ sebagai instalasi acak, $F$ sebagai mutasi data dan $\mathrm{Cr}$ atau recombination kali silang data.

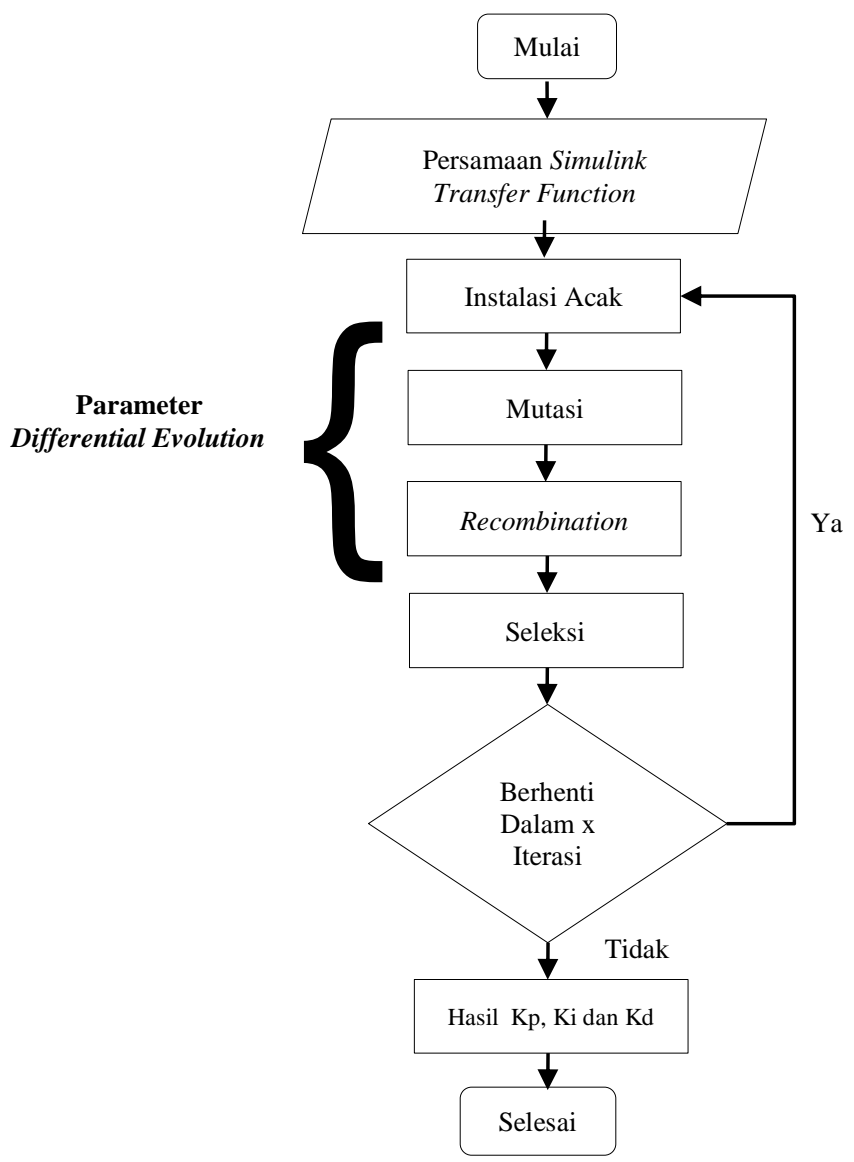

Gambar 4. Flowchart pencarian iterasi menggunakan metode DE.

\section{Hasil dan Pembahasan}

Pada bagian pembahasan ini, dilakukan analisis berdasarkan hasil pengujian jumlah spesies, pengujian parameter kontrol DE, dan pengujian manual tuning kontroler. Hasil Sistem kontrol DE sendiri digunakan untuk mengevaluasi kinerja kontroler yang diusulkan. 


\subsection{Pengujian Parameter DE 1}

Pada pengujian parameter DE 1 ini, dilakuka beberapa variasi nilai spesies/iterasi dengan mengubah nilai setiap pengujiannya. Pada setiap perubahan nilai yang dilakukan terhadap jumlah nilai variasi tersebut menentukan durasi waktu pencarian untuk mendapatkan hasil parameter $K p$, $K i$ dan $K d$. Semakin besar nilai maka pencarian membutuhkan waktu yang lebih lama dalam pencariannya untuk mendapatkan nilai yang paling terbaik.

Tabel 2. Pengujian jumlah spesies.

\begin{tabular}{cccccccc}
\hline $\begin{array}{c}\text { Pengujian Jumlah } \\
\text { Spesies }\end{array}$ & \multirow{2}{*}{$\mathrm{Kp}$} & $\mathrm{Ki}$ & $\mathrm{Kd}$ & \multicolumn{3}{c}{ Respons } & \multirow{2}{*}{ Waktu Naik } \\
\cline { 5 - 7 } & 4,9071 & 4,046 & 0,20536 & 6,1887 & 11,5813 & 0 & 300 \\
20 & 3,3344 & 2,388 & 2,5352 & 9,9961 & 18,1484 & 0,0014 & 78,3060 \\
30 & 3,0314 & 2,5913 & 0,57013 & 9,2372 & 16,7424 & 0 & 100 \\
40 & 5,591 & 4,1561 & 0,55475 & 6,1357 & 11,6174 & 0 & 100 \\
50 & 4,122 & 2,714 & 0,42374 & 9,9274 & 17,1245 & 0 & 100 \\
\hline
\end{tabular}

Gambar 5 menunjukkan sinyal hasil pengujian pada jumlah spesies/iterasi. Percobaan dilakukan dengan mengubah nilai percobaan dengan ukuran yang berbeda-beda yaitu 10, 20, 30, 40, dan 50. Dari hasil pengujian ini didapatkan nilai $K p, K i$ dan $K d$ yang bervariasi. Sebagai contoh, dapat dilihat pada percobaan 2 dengan ukuran 20 didapatkan nilai melebihi batas nilai Set Poin dengan nilai overeshoot 0,0014. Hasil sinyal uji menunjukkan bahwa algoritma memberikan kinerja yang cukup baik dan cukup mudah diterapkan dalam kinerja PID.

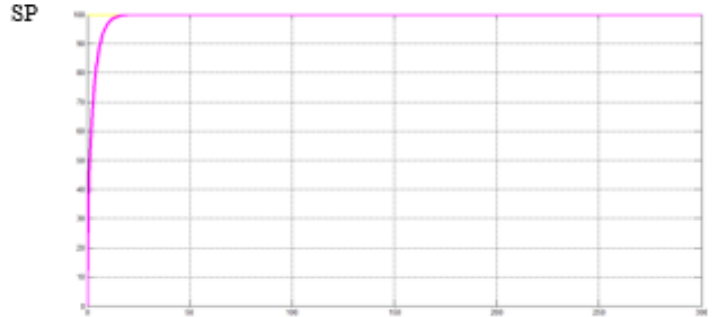

(a) Percobaan 1, 10 Spesies

SP

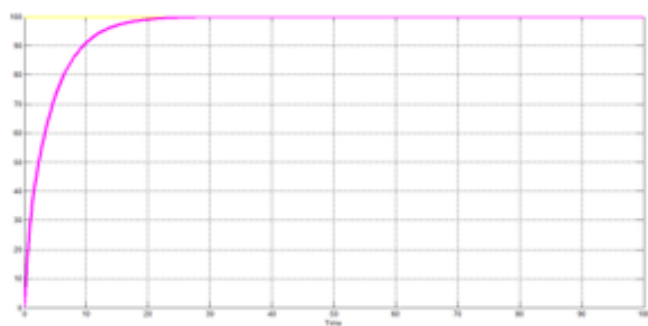

(c) Percobaan 3, 30 Spesies

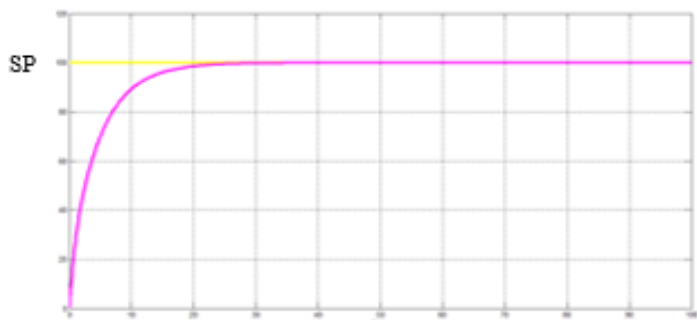

(b) Yercobaan 2, 20 Spesies

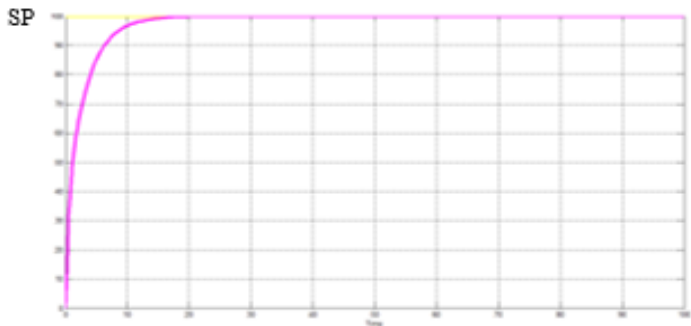

(d) Percobaan 4, 40 Spesies

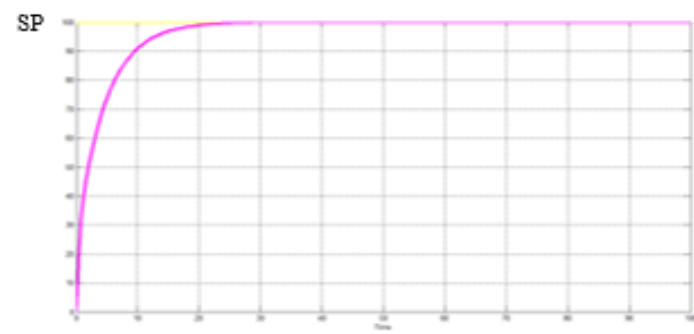

(e) Percobaan 5, 50 Spesies

Gambar 5. Sinyal hasil pengujian jumlah spesies. 


\subsection{Pengujian Parameter DE 2}

Pada pengujian 2 ini dilakukan variasi pada parameter kontrol DE, dengan mengubah nilai setiap pengujiannya. Pada setiap perubahan nilai yang dilakukan jumlah nilai variasi menentukan nilai $K p, K i, \mathrm{Kd}$ dan nilai respons pada sinyal hasil.

Tabel 3. Pengujian parameter kontrol DE.

\begin{tabular}{|c|c|c|c|c|c|c|c|c|c|c|}
\hline \multicolumn{3}{|c|}{$\begin{array}{c}\text { Pengujian Parameter } \\
\text { Kontrol Diferensial } \\
\text { Evolusi }\end{array}$} & \multirow[t]{2}{*}{$\begin{array}{l}\text { Jumlah } \\
\text { Spesies }\end{array}$} & \multirow[t]{2}{*}{$K p$} & \multirow[t]{2}{*}{$K i$} & \multirow[t]{2}{*}{$K d$} & \multicolumn{3}{|c|}{ Respons } & \multirow[t]{2}{*}{$\begin{array}{l}\text { Waktu } \\
\text { Naik }\end{array}$} \\
\hline$G$ & $F$ & $\mathrm{Cr}$ & & & & & $t r$ & $t s$ & ov & \\
\hline 10 & -2 & 0,2 & 10 & 2,081 & 4,0894 & 2,2664 & 4,8113 & 8,3788 & 0,0011 & 27,3899 \\
\hline 20 & 1 & 0,4 & 10 & 1,6314 & 2,0075 & 3,7542 & 10,9361 & 18,9734 & 0,0018 & 278,9377 \\
\hline 30 & 0 & 0,6 & 10 & 12,3388 & 4,9414 & 1,6967 & 6,0039 & 12,7824 & 0,0102 & 297,3831 \\
\hline 40 & 1 & 0,8 & 10 & 2,2799 & 1,8574 & 0,41406 & 12,7733 & 22,8959 & 0 & 300 \\
\hline 50 & 2 & 1 & 10 & 0 & 0,8828 & 0 & 23,5587 & 42,5400 & 0 & 300 \\
\hline
\end{tabular}

Pada Gambar 6. diperoleh sinyal hasil pada parameter kontrol DE. Percobaan dilakukan dengan mengubah nilai $G, F$, dan $C r$. Hasil $K p, K i$ dan $K d$ ditunjukkan pada Tabel 3. Berdasarkan hasil percobaan dengan mengubah nilai parameter DE didapatkan hasil yang cukup baik. Hasil sinyal uji menunjukkan bahwa algoritma masih memberikan nilai terbaik pada hasil pencariannya. Mengingat nilai pengujian yang di rubah adalah parameter DE sendiri, masih memberikan nilai yang cukup baik. Hasil yang ditampilkan adalah nilai yang paling terbaik pada proses pencariannya.

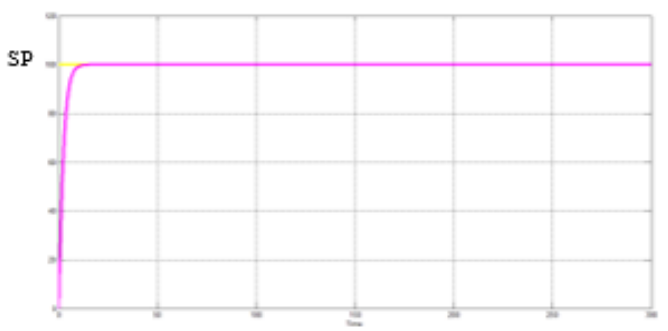

(a) Percobasan $1 \mathrm{G}, 10 ; \mathrm{F},-2 ; \mathrm{Cr}, 0,2$

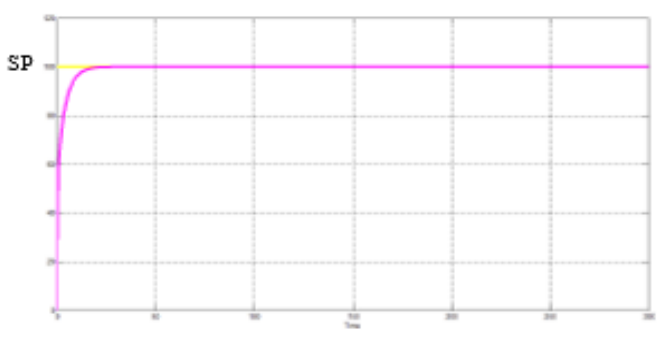

(c)Percobasm $3 \mathrm{G}, 30 ; \mathrm{F}, 0 ; \mathrm{Cr}, 0,6$

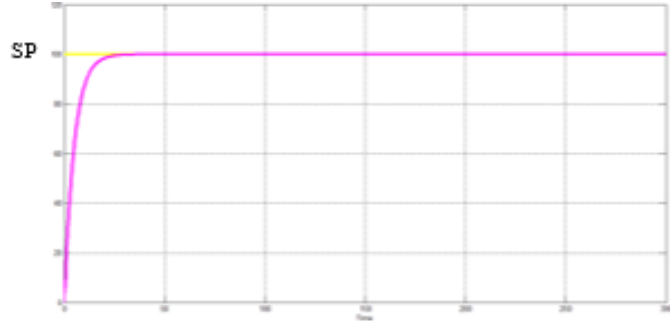

(b) Percobaan $2 \mathrm{G}, 20 ; \mathrm{F},-1 ; \mathrm{Cr}, 0,4$

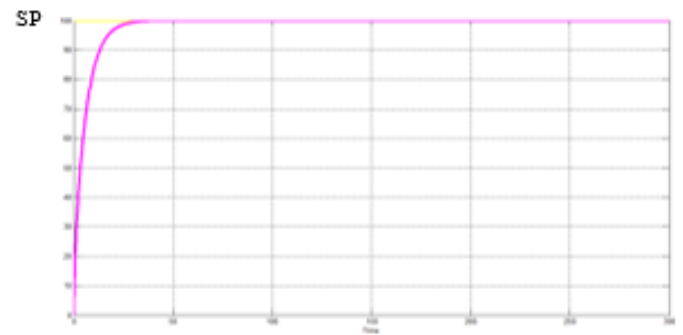

(d) Percobasm $4 \mathrm{G}, 40 ; \mathrm{F}, 1 ; \mathrm{Cr}, 0,8$

SP

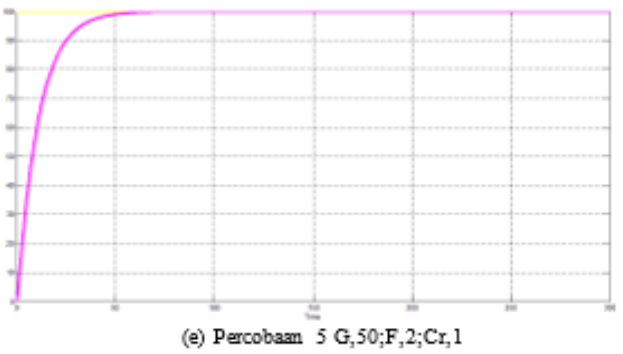

Gambar 6. Hasil sinyal pengujian parameter kontrol DE. 


\subsection{Pengujian Trial dan Error Tuning PID}

Pada pengujian ini, dilakukan variasi terhadap nilai gain/tuning PID DE, dengan mengubah nilai setiap pengujiannya. Pada setiap perubahan nilai $K p, K i, K d$ dimasukkan secara manual atau dengan cara coba-coba, dengan mengubah gain/tuning untuk mendapatkan nilai parameter yang baik.

Tabel 4. Pengujian manual tuning PID.

\begin{tabular}{|c|c|c|c|c|c|c|c|c|c|c|}
\hline \multicolumn{3}{|c|}{$\begin{array}{c}\text { Pengujian Parameter } \\
\text { Kontrol Diferensial } \\
\text { Evolusi } \\
\end{array}$} & \multirow[t]{2}{*}{$\begin{array}{l}\text { Jumlah } \\
\text { Spesies }\end{array}$} & \multirow[t]{2}{*}{$K p$} & \multirow[t]{2}{*}{$K i$} & \multirow[t]{2}{*}{$K d$} & \multicolumn{3}{|c|}{ Respons } & \multirow[t]{2}{*}{$\begin{array}{c}\text { Waktu } \\
\text { Naik }\end{array}$} \\
\hline$G$ & $F$ & $\mathrm{Cr}$ & & & & & $t r$ & $t s$ & $o v$ & \\
\hline 10 & 0,5 & 0.8 & 10 & 5 & 0 & 1 & 0 & 0 & 0 & 8,8661 \\
\hline 10 & 0,5 & 0,8 & 10 & 2 & 5 & 8 & 3,4943 & 9,4728 & 4,0816 & 7,0411 \\
\hline 10 & 0,5 & 0,8 & 10 & 2 & 8 & 6 & 2,2061 & 7,0003 & 9,1331 & 4,5003 \\
\hline 10 & 0,5 & 0,8 & 10 & 3 & 9 & 3 & 1,9773 & 5,4363 & 4,0553 & 4,0566 \\
\hline 10 & 0,5 & 0,8 & 10 & 10 & 25 & 15 & 1,1937 & 7,2840 & 24,9459 & 2,7176 \\
\hline
\end{tabular}

Gambar 7. Menunjukkan sinyal hasil pada manual tuning DE. Percobaan dilakukan dengan mengubah nilai percobaan 1. $K p=5, K i=0, K d=1$. Percobaan 2. $K p=2, K i=5, K d=8$, Percobaan 3. $K p=2, K i=$ 8, $K d=6$, Percobaan 4. $K p=3, K i=9, K d=3$, dan Percobaan $5 . K p=10, K i=25, K d=15$. Hasil $K p, K i$ dan $K d$ ditunjukkan pada Tabel 4. Hasil sinyal uji menunjukkan nilai respons sistem terhadap tuning kurang baik, pencarian tuning manual juga bisa dilakukan dengan mengikuti kaidah pencarian $K p, K i$ dan $K d$.

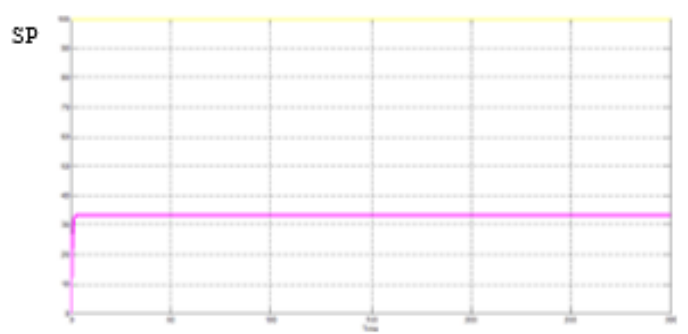

(a) Percobasm $1 \mathrm{Kp}, 5 ; \mathrm{Ki}, 0 ; \mathrm{Kd}, 1$

SP

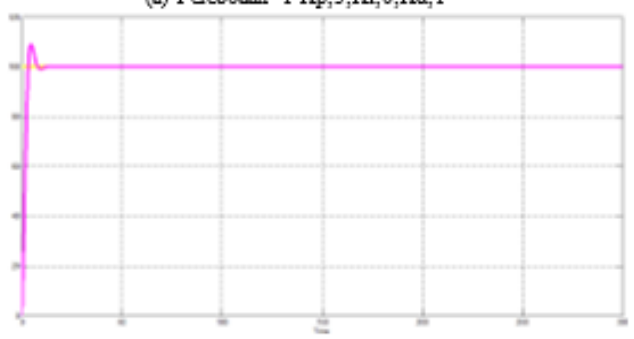

(c) Percobasm $3 \mathrm{Kp}, 2 ; \mathrm{Ki}, 8 ; \mathrm{Kd}, 6$

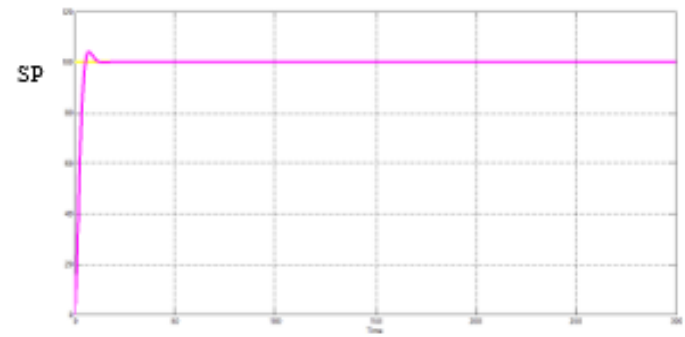

(b) Percobasm $2 \mathrm{Kp}, 2 ; \mathrm{Ki}, 5 ; \mathrm{Kd}, 8$

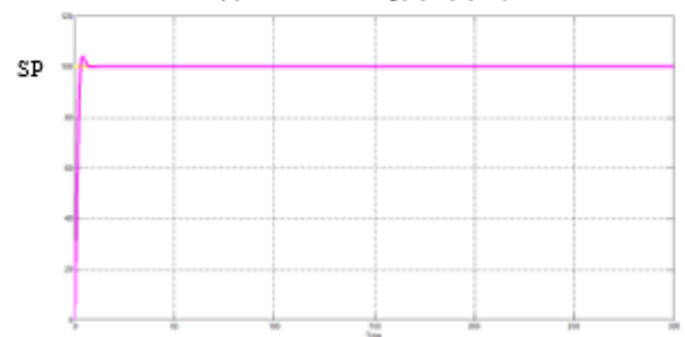

(d) Percobasm $4 \mathrm{Kp}, 3 ; \mathrm{Ki}, 9 ; \mathrm{Kd}, 3$

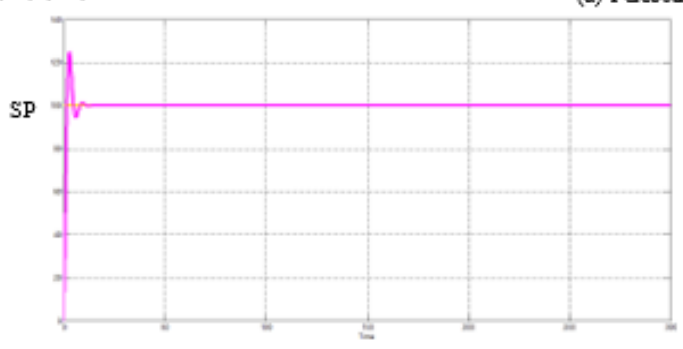

(e) Percobasm $5 \mathrm{Kp}, 10 ; \mathrm{Ki}, 25 ; \mathrm{Kd}, 15$

Gambar 7. Hasil sinyal pengujian manual tuning PID.

\subsection{Pengujian Trial dan Error Tuning dengan Hardware}

Hasil pengujian dengan metode DE akan diimplementasikan ke dalam plan hardware sebagai setting tuning $K p, K i$ dan $K d$, di mana hasil terbaik DE akan digunakan sebagai nilai acuan untuk mendapatkan respons sistem pada PID.

ISSN (e): 2540-9123

ISSN (p): 2502-1982 


\subsection{Pengujian Tuning Hasil Parameter DE 1}

Pengujian tuning dilakukan dengan data pada Tabel 5. Data tabel diambil dari hasil terbaik Pengujian DE 1.

Tabel 5. Pengujian tuning hasil parameter DE 1.

\begin{tabular}{|c|c|c|c|c|c|c|c|}
\hline \multirow{2}{*}{ NO. } & \multirow{2}{*}{$K p$} & \multirow{2}{*}{$K i$} & \multirow{2}{*}{$K d$} & \multicolumn{3}{|c|}{ Respons } & \multirow{2}{*}{$\begin{array}{c}\text { Waktu } \\
\text { Naik }\end{array}$} \\
\hline & & & & $T r$ & $t s$ & $o v$ & \\
\hline 1. & 4,9071 & 4,046 & 0,20536 & 4,1813 & 75,3333 & 4,0000 & 62 \\
\hline 2. & 3,3344 & 2,388 & 2,5352 & 1,5684 & 53,3333 & 2,0000 & 18 \\
\hline 3. & 3,0314 & 2,5913 & 0,57013 & 4,3654 & 64,3333 & 4,0000 & 15 \\
\hline 4. & 5,591 & 4,1561 & 0,55475 & 8,0833 & 91,0000 & 6,0000 & 88 \\
\hline 5. & 4,122 & 2,714 & 0,42374 & 12,3333 & 69,3333 & 4,0000 & 18 \\
\hline
\end{tabular}
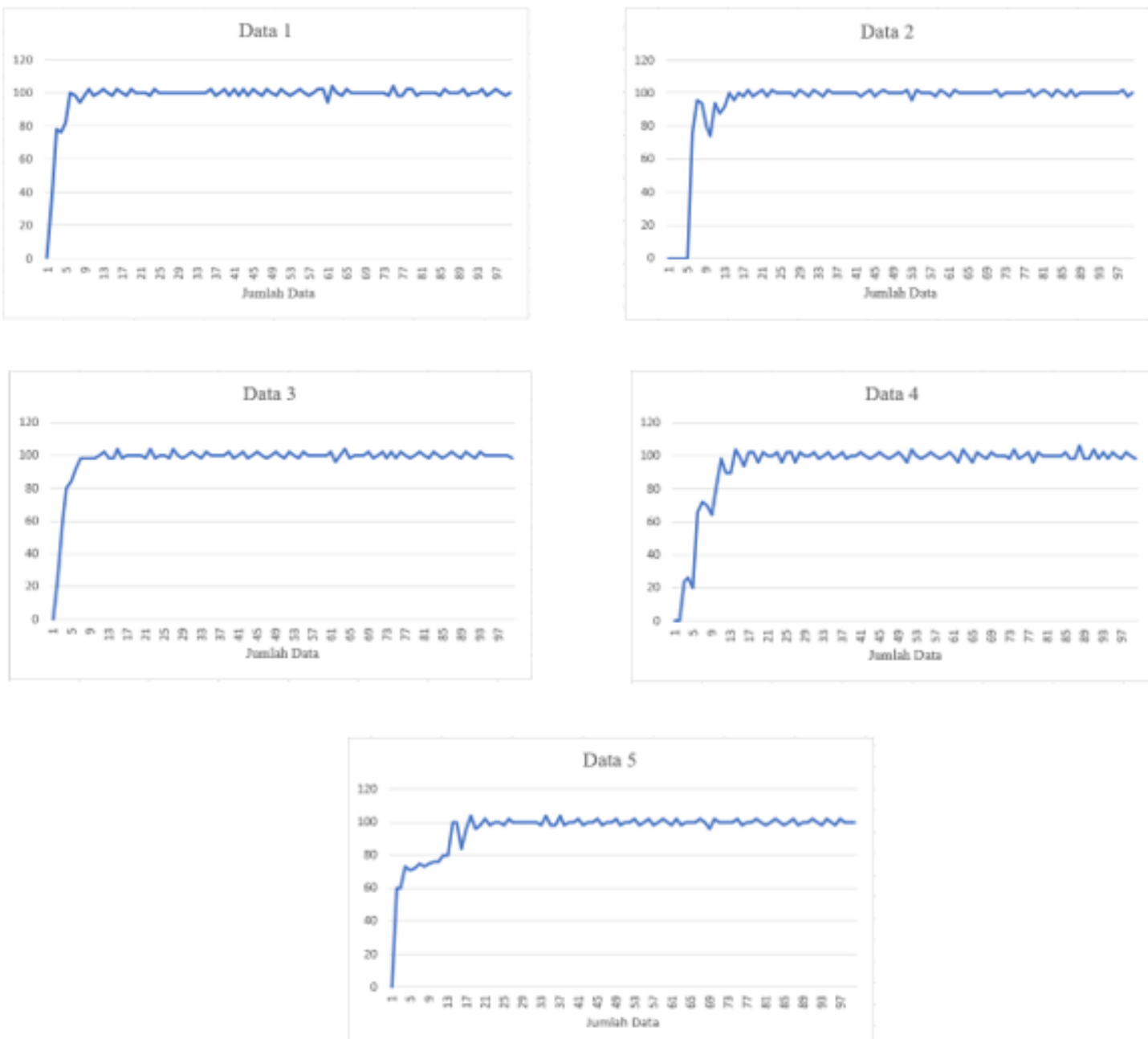

Gambar 8. Sinyal respons pengujian tuning hasil parameter DE 1.

Hasil sinyal respons pengujian tuning DE 1 menunjukkan sinyal respons yang cukup baik pada plan. Hal ini ditunjukkan pada Gambar 8 dengan hasil respons sistem yang stabil dengan mencapai nilai set poin pada putaran motor dc.

\subsection{Pengujian Tuning Hasil Parameter DE 2}

Pengujian tuning dilakukan dengan data pada Tabel 6. Data tabel diambil dari hasil terbaik Pengujian DE 2. Hasil sinyal respons pengujian tuning DE 2 menunjukkan hasil yang cukup baik dengan parameter tertentu, mengingat parameter DE dilakukan ubah variasi pada pencariannya. 
Tabel 6. Pengujian tuning hasil parameter DE 2.

\begin{tabular}{cccccccc}
\hline \multirow{2}{*}{ No. } & \multirow{2}{*}{$K p$} & \multirow{2}{*}{$K i$} & & \multicolumn{3}{c}{ Respons } & Waktu \\
\cline { 5 - 7 } & & & & $t r$ & $t s$ & $o v$ & Naik \\
\hline 1. & 2,081 & 4,0894 & 2,2664 & 2,5000 & 77,3333 & 6,0000 & 6 \\
2. & 1,6314 & 2,0075 & 3,7542 & 5,4318 & 50,3333 & 4,0000 & 8 \\
3. & 12,3388 & 4,9414 & 1,6967 & 7,1429 & 0 & 4,0000 & 21 \\
4. & 2,2799 & 1,8574 & 0,41406 & 4,3990 & 9 & 2,0000 & 14 \\
5. & 0 & 0,88286 & 0 & 2,4333 & 12 & 6,0000 & 7 \\
\hline
\end{tabular}
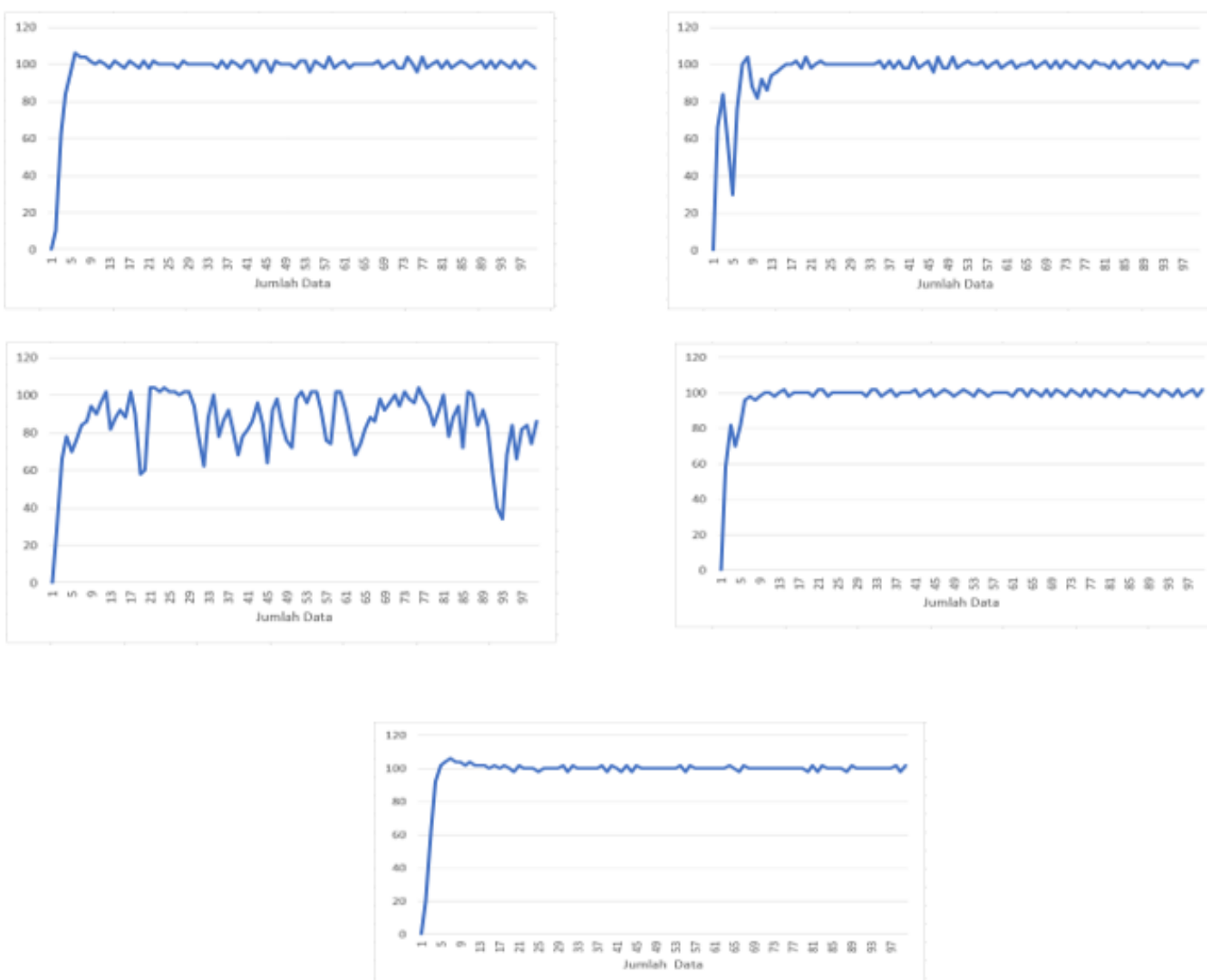

Gambar 9. Sinyal respons pengujian tuning hasil parameter DE 2.

\subsection{Pengujian Trial dan Error Tuning PID pada Hardware}

Pengujian tuning dilakukan dengan data pada Tabel 7. Data tabel diambil dari hasil terbaik Pengujian hasil manual. Hasil pengujian tuning manual menunjukkan respons sistem yang tidak baik, ditunjukkan seperti pada Gambar 10 dimana nilai tuning harus dilakukan beberapa kali percobaan untuk mendapatkan nilai yang baik pada setting tuning gain $K p, K i$ dan $K d$.

Tabel 7. Pengujian trial dan error tuning PID pada hardware.

\begin{tabular}{|c|c|c|c|c|c|c|c|}
\hline \multirow{2}{*}{ No. } & \multirow{2}{*}{ Kp } & \multirow{2}{*}{$\mathrm{Ki}$} & \multirow{2}{*}{$\mathrm{Kd}$} & \multicolumn{3}{|c|}{ Respons } & \multirow{2}{*}{$\begin{array}{l}\text { Waktu } \\
\text { Naik }\end{array}$} \\
\hline & & & & $t r$ & ts & ov & \\
\hline 1. & 5 & 0 & 1 & 11,5000 & 96,3333 & 4,0000 & 94 \\
\hline 2. & 2 & 5 & 8 & 1,7708 & 100 & 12,0000 & 15 \\
\hline 3. & 2 & 8 & 6 & 2,2571 & 92,5000 & 12,0000 & 23 \\
\hline 4. & 3 & 9 & 3 & 1,5660 & 50 & 10,0000 & 58 \\
\hline 5. & 10 & 25 & 15 & 1,6091 & 22,2222 & 10,0000 & 43 \\
\hline
\end{tabular}



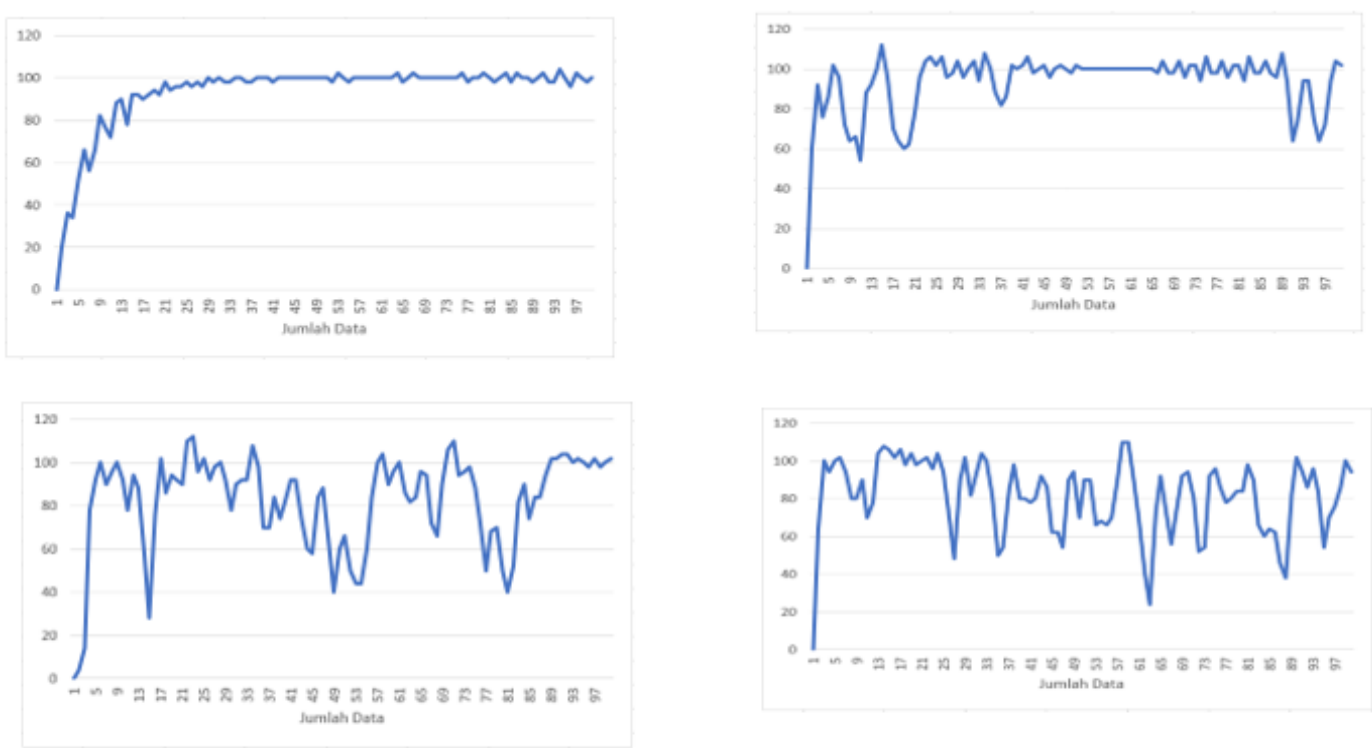

Gambar 10. Sinyal Respons trial dan error tuning PID pada hardware.

\section{Kesimpulan}

Setelah dilakukan penelitian dan pengujian dengan menggunakan metode ini, dapat disimpulkan bahwa metode ini terintegrasi dengan baik yang artinya tuning PID dengan menggunakan metode DE dapat memberikan pengoptimalan dan efektivitas terhadap PID mikrokontroler. Proses pencarian dilakukan dengan pendekatan metode DE yang membuktikan bahwa hasil parameter DE 1 dan DE 2 pada matlab memberikan nilai terbaik pada pencariannya dengan size $=10$ dari hasil DE 1 dengan nilai $K p=4,9071 ; K i=4,9071 ; K d=0,20536$ dan nilai $\mathrm{rad}=0$. DE 2 pada pengujian dilakukan dengan mengubah nilai parameter DE sendiri dengan size $=10$ dari hasil De 2 dengan nilai $K p=2,081 ; K i=4,0894 ; K d=2,2664$ dan $\operatorname{rad}=0,0011$. Hasil parameter yang digunakan adalah nilai terbaik pada pencariannya yang digunakan pada implementasi motor dc.

\section{Ucapan Terima Kasih}

Pada kesempatan ini penulis mengucapkan terimakasih yang sebanyak-banyaknya kepada bapak pembimbing yang sudah mendukung dan melakukan riset dalam penelitian ini.

\section{Referensi}

[1]. A. Gosh, S. Das, R. Mallipeddi, A. K. Das, and S. S. Dash, "A Modified Differential Evolution with Distance-based Selection for Continuous Optimization in Presence of Noise," IEEE Access, vol. 5, pp. 26944-26964, 2017, doi: 10.1109/ACCESS.2017.2773825. 
[2]. A. Ma'Arif, H. Nabila, Iswanto, and O. Wahyunggoro, "Application of Intelligent Search Algorithms in Proportional-Integral-Derivative Control of Direct-Current Motor System," J. Phys. Conf. Ser., vol. 1373, no. 1, 2019, doi: 10.1088/1742-6596/1373/1/012039.

[3]. B. Guan, Y. Zhao, and Y. Li, "DESeeker: Detecting Epistatic Interactions Using a TwoStage Differential Evolution Algorithm," IEEE Access, vol. 7, pp. 69604-69613, 2019, doi: 10.1109/ACCESS.2019.2917132.

[4]. B. Yang, Z. Zhang, and Z. Sun, "Computing Nonlinear LTS Estimator Based on a Random Differential Evolution Strategy,” Tsinghua Sci. Technol., vol. 13, no. 1, pp. 59-64, 2008, doi: 10.1016/S1007-0214(08)70010-5.

[5]. FAHMIZAL, F. et al. (2019) 'Robot Inverted Pendulum Beroda Dua (IPBD) dengan Kendali Linear Quadratic Regulator (LQR)', ELKOMIKA: Jurnal Teknik Energi Elektrik, Teknik Telekomunikasi, \& Teknik Elektronika. doi: 10.26760/elkomika.v7i2.224, 7(2), pp. 224-237.

[6]. L. U. Factor, "Congestion Management of Power System with Interline Power Flow Controller Using Disparity," vol. 1, no. 3, pp. 76-85, 2015M. G. Villarreal-Cervantes, A. Rodriguez-Molina, C. V. Garcia-Mendoza, O.

[7]. Penaloza-Mejia, and G. Sepulveda-Cervantes, "Multi-Objective On-Line Optimization Approach for the DC Motor Controller Tuning Using Differential Evolution," IEEE Access, vol. 5, pp. 20393-20407, 2017, doi: 10.1109/ACCESS.2017.2757959.

[8]. R. A. Sarker, S. M. Elsayed, and T. Ray, "Differential evolution with dynamic parameters selection for optimization problems," IEEE Trans. Evol. Comput., vol. 18, no. 5, pp. 689707, 2014, doi: 10.1109/TEVC.2013.2281528.

[9]. W. Lianghong, W. Yaonan, Z. Shaowu, and T. Wen, "Design of PID controller with incomplete derivation based on differential evolution algorithm," J. Syst. Eng. Electron., vol. 19, no. 3, pp. 578-583, 2008, doi: 10.1016/s1004-4132(08)60123-1.

[10]. W. Shahzad, Y. Ahsan, and E. Ahmed, "Drug Design and Discovery using Differential Evolution,” J. Appl. Environ. Biol. Sci., vol. 6, no. 12, pp. 16-26.

[11]. Y. L. Li, Z. H. Zhan, Y. J. Gong, W. N. Chen, J. Zhang, and Y. Li, "Differential Evolution with an Evolution Path: A DEEP Evolutionary Algorithm," IEEE Trans. Cybern., vol. 45, no. 9, pp. 1798-1810, 2015, doi: 10.1109/TCYB.2014.2360752. 